\title{
医療用デバイスとめっきによる高機能化
}

\author{
小幡勤 ${ }^{\mathrm{a}}$
}

a 富山県工業技術センター 中央研究所 ( ₹ 933-0981 富山県高岡市二上町 150)

\section{Medical Chip Devices Functionalized by Plating Technology}

\section{Tsutomu OBATA ${ }^{\text {a }}$}

${ }^{a}$ Central Research Institute, Toyama Industrial Technology Center(150, Futagami-machi, Takaoka-shi, Toyama 933-0981)

Keywords : Medical Device, Antibody, Plating, MEMS, Magnetic Thin Film

\section{1.はじめに}

次世代医療として, ES 細胞, iPS 細胞などによる再生医 療と並んでテーラーメイド医療が注目されている。患者の疾 患に対する治療方法は，これまで画一的な療法を適用するこ とが中心となってきた。しかし，このような患者に対して同 じ治療方法を施すやり方から，患者個々の疾患の状態に対し て有効な最も適期した治療を行うことが必要であることがわ かってきた。個々にあった医療を行うことは, 治療がより有 効でかつ副作用についても最小限に抑えられる可能性も秘め ている。なかでも抗体医薬は，ヒトがもともと体内に有する 免疫機能を利用したものである。血液中のリンパ球が創りだ す抗体を利用することで，副作用のない薬も実現可能と考え られている。

また近年，上記抗体医薬を開発する技術として，細胞を一つ 一つ取り扱いそれを個々に評価するシステムの開発が行われて いる。個々の細胞の特性, 性質などを把握することで, 細胞の 刺激に対する応答選別や病変などの予兆をモニターしようとい うような用途へ応用されようとしている。例えば, 我々のグルー プが行っているような細胞に対しての抗原刺激による反応を観 察することで，血液中に低頻度で存在する抗原特異的抗体分泌 細胞のスクリーニングが可能である ${ }^{1) \sim 3)}$ 。また，個々の細胞の硬 さを計測することで病気発症の予知や健康状態を把握するなど への応用も考えられている ${ }^{4)}$ 。

富山大学大学院医学薬学研究部免疫学と富山県工業技術セ ンターは共同で, 抗体医薬開発に必要な抗原特異的抗体産生 細胞のスクリーニング技術を開発している。ある特定の抗原 例えばインフルエンザに対して免疫反応を示すリンパ球は非 常に少ないため，なるべく多くの候補の中から効率よく選別 できる技術が必要である。我々が開発したシリコンマイクロ ウェルアレイチップ ${ }^{5)}$ は, 微細加工技術である MEMS (Micro Electro Mechanical Systems) 技術を応用して表面に約 10 ミク ロン程度の穴を数十万個形成し，そこへリンパ球を一つ一つ 収容することで単細胞での評価が可能となっている。しかし ながら，シリコンをべースとした本システムは, 細胞の投入
量に対するウェルへの収容率が悪いことから 1 回の細胞投入 でのウェルへの細胞充填率は $10 \sim 20 \%$ 程度とあまりよい 数值が得られていない。実際は, チップ上への細胞の播種と ウェルへの収容の作業を数回繰り返すことで実用的な充填率 を得ている。しかしこの作業は細胞を弱らせるばかりか, 作 業者の熟練度によって結果のばらつきが起こり, システムを 広く普及させるにはこの投入した細胞をいかに効率よく利用 するか ( = 細胞利用率)を向上させるかが鍵となっている。

このシリコンベースのチップは, 細胞のウェルへの収容を 重力による沈降に任せている。よってチップ上に播種された 細胞は，懸濁液を浮遊しながら重力で沈降していく過程で偶 然ウェルに収まっていく。つまり実用化に耐えうる効率の高 いシステムを構築するためには細胞に外力を加えることで強 制的にチップ上に配列させることが必要となる。

本稿では，我々が開発しためっきによる磁性膜を用いて効 率よく細胞をスクリーニング可能なシステムを例に医療用デ バイスのめっきによる高機能化の可能性について解説する。

\section{2. 磁性めっき膜}

めっきによって作製される磁性膜は，磁気記録媒体である ハードディスクドライブ $(\mathrm{HDD})$ をはじめとして，磁気へッド， 磁気センサなどに応用されている。我々が開発しているシス テムでは，一般的なニッケルめっき膜や軟磁性膜である $\mathrm{Co}-$ $\mathrm{Ni}-\mathrm{Fe}$ 三元合金などを利用した。関東学院大学の竹田ら ${ }^{6)}$ は, ホウ酸 $0.40 \mathrm{~mol} / \mathrm{dm}^{3}$, 塩化アンモニウム $0.20 \mathrm{~mol} / \mathrm{dm}^{3}$, 硫酸 ニッケル $0.20 \mathrm{~mol} / \mathrm{dm}^{3}$ ，硫酸コバルト $0.0875 \mathrm{~mol} / \mathrm{dm}^{3}$ ，硫酸 鉄 $0.045 \mathrm{~mol} / \mathrm{dm}^{3}$ ， ドデシル硫酸ナトリウム $(\mathrm{SDS}) 0.01 \mathrm{~g} / \mathrm{dm}^{3}$ で細胞捕獲用磁性膜形成に用いる Co-Ni-Fe 三元合金めっき 浴を建浴した。これをべースとして基本浴から構成される金 属塩を 1 種類除いて，二元合金の磁性めっき膜の磁気特性を 評価している。振動試料型磁力計(VSM)を用いた評価では, $\mathrm{Ni}$ を除いた $\mathrm{Co}-\mathrm{Fe}$ 浴での磁性膜の磁束密度は最大の $\mathrm{Br}$ 值を 示した。ここで $\mathrm{Br}$ 值を比較すると, Fe が磁束密度の大きさ を左右することがわかった。さらにこの Co-Fe 浴にて電流密 度による磁束密度の変化を評価している。このとき $\mathrm{Br}$ 值は 
ある值で最大值をとった後, 電流密度を上げるに従って $\mathrm{Br}$ 值が低下する現象が見られた。これは磁性膜の結晶性が影響 しているものと思われ, 最大の $\mathrm{Br}$ 值を示した電流密度での 磁性膜の SEM 観察では, 微細な結晶粒の成長が観察されて いる。このようにして作製された磁性膜は, 半導体集積回路 製造における要素技術の一つフォトリソグラフィー技術に よって数ミクロンのドット状に加工される。ニッケルめっき 膜は比較的形成が容易であることから医療現場から要求され る用途も広範囲に対応できる。また $\mathrm{Co}-\mathrm{Ni}-\mathrm{Fe}$ 膜は軟磁性 であるため，高い透磁率により細胞を効率よく引き寄せ，ま た保持力が小さいことから磁性膜に捕獲した細胞の取り出し も容易となる。いずれのめっき膜も電気めっきにより形成す る。下地電極は，スパッ夕などによって形成された導電膜あ るいは無電解めっきによる Ni-P 非磁性めっき膜などを利用 している。めっきによる磁性膜形成は, 浴組成や温度だけで なく, 基板の前処理条件も重要であり次に述べる微小なス ポットパターンを形成する際は特に気をつける必要がある。

以上のようにめっき法により磁性膜は形成されるが，アレ ルギーや生体毒性を考慮して, 実用段階ではさらに周辺技術 を検討していかなければならない。

\section{3. 磁気スポットアレイの形成}

磁性めっき膜により構成される磁気スポットは, 半導体集 積回路製造技術であるフォトリソグラフィーにて形成される。 微細なパターンを形成可能な本技術を利用することで，基板 であるガラスなどの表面に数万〜数十万個の磁性膜によるマ イクロスポットが形成可能である。磁性膜の形成方法にはス パッタ蒸着法もあるが，特にマグネトロンスパッタ装置では 磁性膜の成膜速度が遅いため, 厚膜化には不向きで生産効率 が著しく劣る。また磁気テープなどに使われる塗布型コート 材も細胞を吸引するのに必要な磁力が得られにくいため検討 から外している。今回解説する磁気スポットアレイは，大量 生産が可能で比較的小ロットから効率よく対応可能なめっき 技術にて形成されている。めっき技術は，スパッ夕蒸着とは 違い真空䨌囲気を必要としない。つまり大がかりな設備を必 要とせず，ビーカー一つからでもその成膜工程が実現できる。 また, 真空排気などの時間のかかる工程ではないのでスルー プットも優れている。しかし，前述のようにフォトリソグラ フィーによって開口した部分へのめっきを行う際は，めっき 前の微小パターンへのめっき液の十分な浸透はもとより, フォ トレジストのスカムにも注意する必要がある。数ミクロンの パターンが多数配列される磁気スポットアレイの場合, フォ トレジストのスカムによってめっき膜の密着性が著しく劣っ てしまうことがある。よって，フォトレジスト，現像条件な どを十分検討し，清浄な下地膜が露出するように気をつける。
図 1 は磁気スポットアレイの製造方法例である。はじめに, 基板に下地電極となる金属膜を蒸着あるいは無電解めっき法 などにより形成する。その電極上にフォトレジストを塗布し， スポットパターンが描かれたフォトマスクを透して露光, 現 像を行うとスポットパターン上に下地電極が露出する。この 後スルファミン酸浴による電気めっきを施すことで露出開口 部にニッケル膜によって構成される磁性めっき膜が成長する。 ここではニッケルめっき液は市販のものを利用し, 液温 $50{ }^{\circ} \mathrm{C} に て$ 行っている。フォトレジストはこの工程後にアセ トンなどの有機溶剂により剥離される。このときめっきの膜 厚は 2 〜 ミロン程度である。薄すぎると磁性が弱いため 細胞の捕獲が難しく，逆に厚いとめっき膜がポール状に基板 上に形成されるため, 膜上への単細胞のみの捕獲が難しくな る。また，スポットのサイズは一つのスポットに 1 つの細胞 のみを捕獲するためには重要なパラメータである。ターゲッ トとする細胞, 例えばリンパ球のサイズは約 8 ミクロン程度 である。よってスポットサイズが十数ミクロンと大きくなる と, 一つのスポットに複数の細胞がトラップされてしまう。 よってスポットサイズは細胞の大きさよりも小さくすること が好ましく，リンパ球などを対象とする場合，例えば 5 ミク ロンくらいの大きさが一つの基準となってくる。図 2 はス ポットサイズを 5 ミクロンと 10 ミクロンに設定し, 約 6 ミ クロンの磁気ビーズを $\mathrm{Co}-\mathrm{Ni}-\mathrm{Fe}$ 膜へトラップさせた結果 である。基板上にばらまかれた磁気ビーズは，基板下に配置

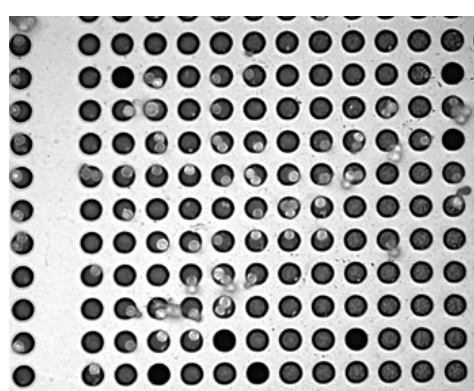

(a) 10 ミクロン径

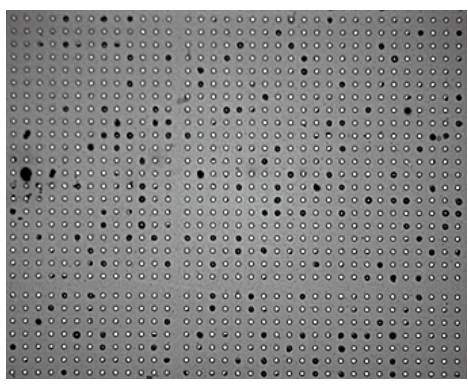

(b) 5 ミクロン径

図 2 磁気スポット径と磁気ビーズ

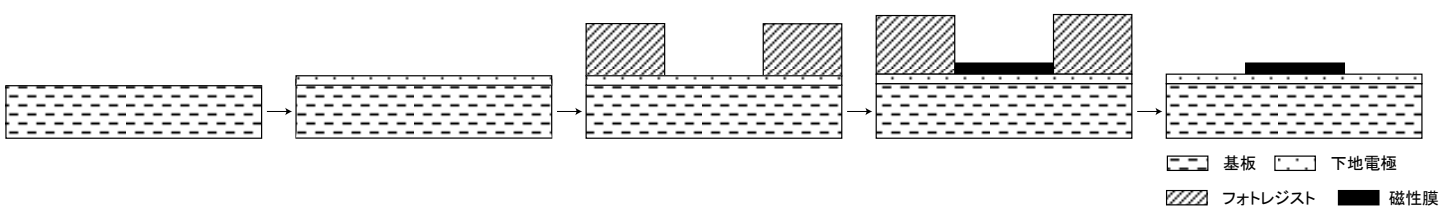

図 1 磁気スポットアレイの製造方法例 
された永久磁石から伸びて, 磁気スポットへ入る磁束に捉え られ，磁気スポット上へ引き寄せられる。この磁気ビーズは， 10 ミクロンのスポットサイズだと複数の磁気ビーズが一つ のスポットに捕獲されるが， 5 ミクロンのスポットサイズだ と一つのスポットに一つの磁気ビーズのみが捕獲されている。 これらの結果から磁気スポットのサイズをターゲットにより 最適化することで容易に 1 細胞レベルでの取り扱いが可能で あることがわかる。

\section{4. 抗原特異的抗体産生細胞のスクリーニング}

磁気による生体細胞の取り扱いについては，すでにいくつ かのグループによって行われている。名古屋大学の K.Ino ら のグループ7) は, ネオジウム磁石を機械加工によってマイク ロポール状にし，薄いシートを介してシート上の細胞を配列 させることを試みている。ハーバード大学の H.Lee ${ }^{8)}$ は, CMOS 技術を組み合わせてチップ表面に 10 ミクロン程度の マイクロコイルアレイを形成し, 細胞一つ一つをマニピュ レーションすることを実現している。またコロンビア大の M.Tanase ${ }^{9)}$ ら, 電気化学析出によってニッケルのナノワイ ヤーを形成し，ナノワイヤーに磁極をつくることでその両端 に細胞を固定することに成功している。富山大学医学薬学研 究部の村口・岸のグループは筆者と共同で, シリコン型マイ クロウェルアレイチップを使って，特定の抗原に対して結合 する抗体を産生する細胞をスクリーニングする技術である，

「ISAAC (Immunospot-array assay on a chip)法」を開発し, 従 来 1 〜 ケ月必要とした工程を 1 週間まで一気に短縮させた ${ }^{10)}$ 。 本技術は, マイクロウェルアレイに1つに対し，1つのリン パ球を収容させ, これら個々の細胞が産生する数十万種類以 上に及ぶ抗体をピンポイントで選別可能にしている。本技術 の特色は，マイクロウェルに収容されている各々の細胞が産 生する抗体をチップ表面に固定させさらにその上から蛍光標 識した抗原をばらまくと, その抗原と親和性の高い抗体と結 合することから, 抗原に対して免疫反応を示す抗体を産生す るリンパ球が特定できる。図 3 は実際にB型肝炎の抗体を スクリーニングした例 ${ }^{1}$ である。マイクロウェルの周りが 光っているところの細胞 (矢印) が B 型肝炎の抗体を産生し ている。抗原の蛍光標識は, 細胞の蛍光標識色のグリーン色 と異なるオレンジ色としている。よってそれぞれの蛍光を 別々に観察した結果をマージしてやれば，容易にスクリーニ

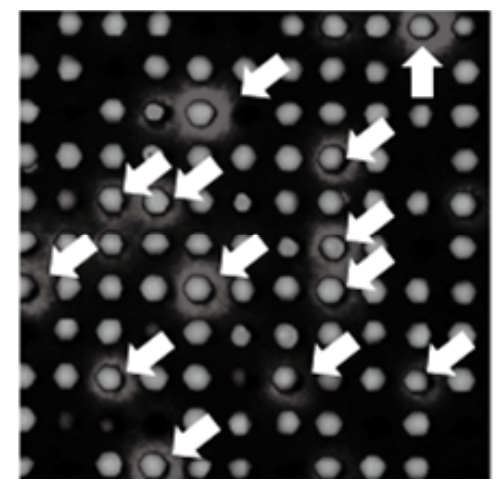

図３ＩSSAC 法によるスクリーニング
ング結果を得ることができる。また抗体と抗原の親和性(抗 体と抗原間の結合性)がオレンジ色の強度として現れるので, より抗原を抑えるのに適した抗体を産生する細胞の選別が可 能となっている。さらに本技術では, 複数の抗原に結合する 抗体を同時に観測することも可能である。抗原に修飾する蛍 光色素の種類を変えることで, 同じ細胞群に対して複数のス クリーニングを実施することができる。従来は抗原で刺激さ れたリンパ球内部の $\mathrm{Ca}^{+}$イオン濃度の上昇を, 細胞にロー ディングされた蛍光色素によってモニターすることで抗原特 異的抗体産生細胞のスクリーニングを行っていた ${ }^{11)}$ 。しか しながら, ターゲットとしている抗原による刺激以外にも反 応してしまうことがありスクリーニング性能が十分でなかっ たが, 本 ISAAC 法では非常に優れたスクリーニング性能を 示すことがわかっている。しかし，現状のシリコンをべース としたチップシステムでは, 細胞のウェルへの導入が効率的 ではないため, 例えば実際の臨床での応用では被検者に対し て負担を強いることになる。これに対して本磁気スポットア レイチップは, 細胞の一つ一つを強制的に配列させることが 可能なため, ISAAC システムと組み合わせることでスクリー ニング性能の大幅な向上が期待できる。

\section{5. 細胞の回収と抗体の生産}

図４は，シリコン型マイクロウェルアレイチップを用いた 際の抗体スクリーニングのプロトコールである。磁気スポッ トアレイチップでも同様の細胞操作を行う。磁気スポットに トラップされた細胞は，マイクロピペットなどにより吸引す ることにより容易に回収される。回収した目的細胞から mRNAを取り出し，これを鋳型とすることで DNAを合成， 増幅する RT-PCR 法 (Reverse Transcription Polymerase Chain Reaction: 逆転写ポリメラーゼ連鎖反応)によって, cDNA を 合成, 増幅を行う。この cDNAを CHO (Chinese Hamster Ovary：チャイニーズハムスターの卵細胞) 細胞などの発現べ クターに組み込み導入することで目的の抗体を産生する。こ のような方法によって，抗体を人工的に産生させることがで きれば，特定の疾患に効能がある抗体医薬が開発できるよう になる。通常, 抗体の発見から市販まで 8 年程度の期間を要

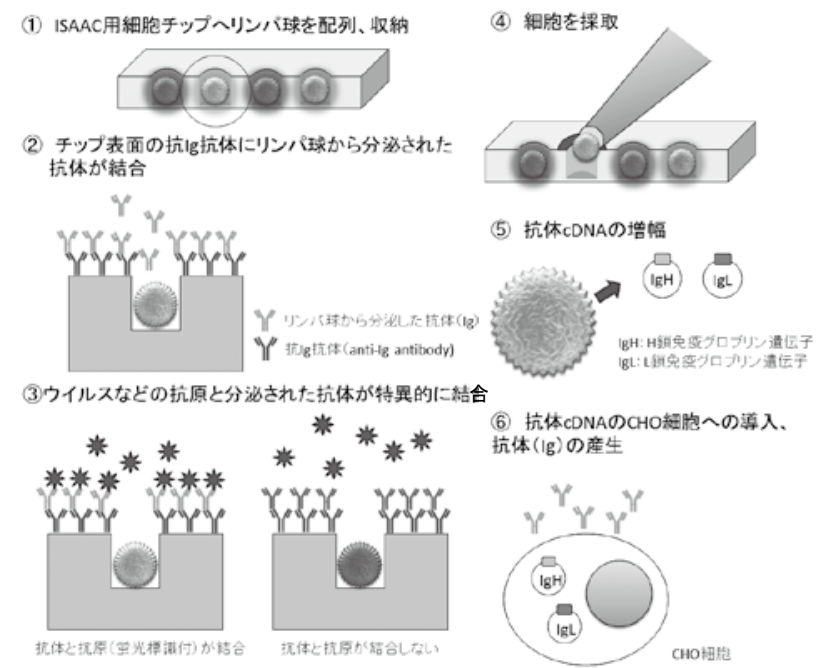

図 4 抗体スクリーニングのプロトコール 
すると言われており，幸運にも目的の抗体の取得に成功して も,さらに地道な作業を続けていく必要がある。

\section{6. 磁気スポットアレイチップの試作と評価}

磁気スポットアレイチップには，マイクロウェルを有する マイクロウェル型と前述の基板に磁気スポットを形成しただ けの平面型の 2 種類がある。マイクロウェル型は, 従来のシ リコン型マイクロウェル型細胞チップの底に磁気スポットを 形成したような形態となるが，ガラス基板ベースにビルド アップによる樹脂マイクロウェルを形成することでシリコン プロセスを使わなくても簡単にチップが製作できる。しかし ながら ISAACによるスクリーニングは, 生物学・医学にお ける研究や各種検査に一般的に用いられている蛍光顕微鏡を 必要としており，このような形態では樹脂などからの自家蛍 光によるバックグラウンドの影響により観察が困難になる。 一方平面型は，ガラスなどの基板に磁気スポットを形成した だけで実現可能で, 非常に簡単な工程で大量生産も可能, 前 述の自家蛍光などの影響もない。とくに簡易検査用途では安 価で大量にディスポーザブルなチップが求められるため, 平 面型は非常に優れたアイテムとなりうる。

先に紹介した図 1 は平面型磁気スポットアレイチップの試 作工程である。この時点で所望するチップとしての性能面は 完成しているが, ニッケルの生体毒性などを考慮して, PDMS やポリパラキシリレンなどの保護膜をコートしてやる。 マイクロウェル型の場合は, さらにフォトリソグラフィー工 程を追加するなどをしてチップを形成する。

完成した磁気マイクロウェルアレイチップの評価について は, ダミーとして細胞の大きさに近い大型磁気ビーズ $(6$ ミ クロン径〜)によるものと実際に細胞表面に磁気ビーズを修 飾させたもので行っている。生体細胞での評価の場合, 細胞 の粘性と鮮度に結果が左右されることもあるため, 磁気ビー ズでの評価はチップ性能の傾向を知るには最適である。3000 ガウス程度の垂直磁化された永久磁石を用意し, その上に チップを固定し, 大型磁気ビーズを播種する。播種されたビー ズは数秒で磁気スポットへ固定される。シリコンチップで問 題となっていたウェル以外へのビーズの浮遊は見られず，ほ ぼ全スポットにビーズが固定され，スポット間にはビーズは 観察されない。しかしここで注意が必要なのは, 磁気ビーズ での評価があくまで傾向を知るための手段であり，実際の生 体細胞での挙動とは異なることである。生体細胞での評価の 場合, その細胞の接着性や大型の磁気ビーズと違いナノサイ ズの磁気ビーズを表面に修飾する形となるので, 磁気吸引に よる効果は劣ってしまう。しかし，大型磁気ビーズの活用は， 磁気スポットアレイチップの工業化において, 信頼性評価な どの手段として有効であり検討を続けている。例えば，細胞 とより近い評価をする手段として，細胞の大きさに近い蛍光 ビーズにナノサイズの磁気ビーズを修飾する方法がある。図 5 は約 5 ミクロンの蛍光ビーズ表面を N-ヒドロキシスクシン イミド基( $\mathrm{NHS}$ 基)で活性させ, アミノ基 $\left(\mathrm{NH}_{2}\right.$ 基)をリガン ドとして修飾した磁気ビーズを結合させたものである。これ らは特別な前処理なしに混ぜることだけで容易に反応するた め, 工学分野の技術者でも蛍光顕微鏡を利用すれば生体細胞
に近いレベルでの評価ができる。

次に生体細胞での性能評価を試みた。生体細胞を利用した 評価については, 富山大学医学薬学研究部内にて実施した。 生体細胞には水溶性ビタミンであるビオチンを結合(ビオチ ン化)させ標識とし，これと非常に強く結合する糖タンパク 質の一種であるストレプトアビジンが固定された磁気ビーズ を結合させることで磁気標識している。なお, 細胞はオレゴ ングリーン蛍光標識を行い, チップ上での配列状況を蛍光顕 微鏡で緑色の発光でモニターできるようにした。図 6 はシリ コン型と磁気スポット型(マイクロウェル型)における細胞の 捕獲の様子を時系列で観察したものである。磁気スポット型 は 20 秒程度ですでに移動する細胞が観察されず，スポット に整然と配列されていることがわかる。逆にシリコン型は浮 遊している細胞が常に観察され，少しずつチップ上に落ちて いく様子が観察される。その沈降に要する時間は 5 分程度で, すべての細胞の沈降にはそれ以上の時間が必要と思われる。 またシリコン型は重力による沈降に頼っているため, マイク ロウェル以外の場所にも細胞が観察される。これらの細胞は, スクリーニングの際にエラーとなるので, 洗浄にて取り除く 必要がある。しかし，この洗浄の際に，せっかくウェルに収 容された細胞までも取り除かれる，あるいは移動してしまう ことがあり, その操作には熟練度が求められている。以上か ら, 磁気スポット型が従来のシリコン型に比較して, 無駄な く効率よく細胞を配列可能でかつ省力化と熟練を要しないデ バイスであることがわかった。またこれらの結果は, 本シス テムの自動化に際しても有利であり，これまで人に頼ってい た細胞を配列させるプロセスを機械化できる可能性を提供し，

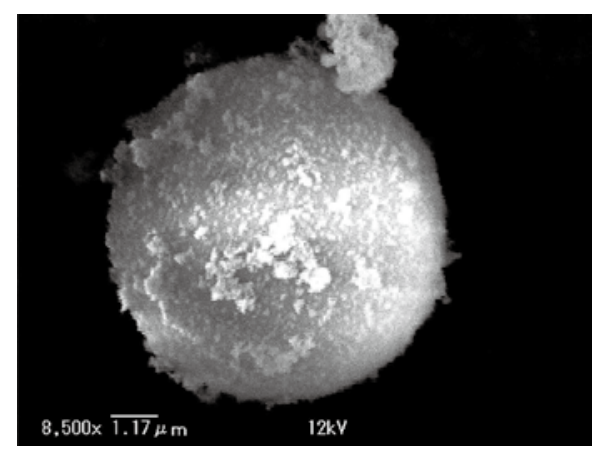

図 5 磁気ビーズ修飾された蛍光ビーズの SEM 写真

\section{シリコン型}

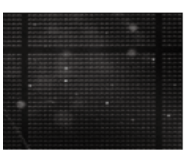

$0 \mathrm{sec}$

磁気スポツト型

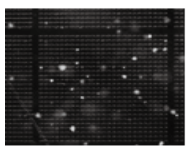

$0 \mathrm{sec}$

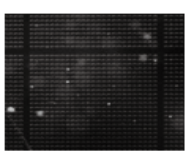

$10 \mathrm{sec}$

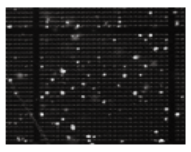

$10 \mathrm{sec}$

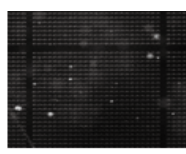

$20 \mathrm{sec}$

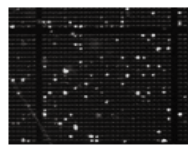

$20 \mathrm{sec}$

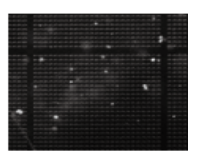

$60 \mathrm{sec}$

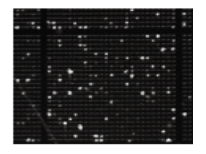

$60 \mathrm{sec}$
図 6 シリコン型と磁気スポット型の細胞誘引の様子 
表 1 シリコン型と磁気スポット型の細胞利用率

\begin{tabular}{cccc}
\hline & 細胞投入量 & 充填率 & 細胞利用率 \\
\hline シリコン型 & 総ウェル数の 4 倍個 & $47.2 \% \mathrm{avg}$ & $11.8 \%$ \\
磁気スポット型 & 総ウェル数の 0.65 倍個 & $60.3 \% \mathrm{avg}$ & $92.7 \%$ \\
\hline
\end{tabular}

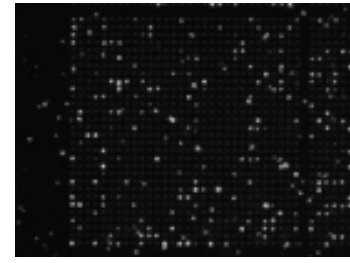

(a) シリコン型

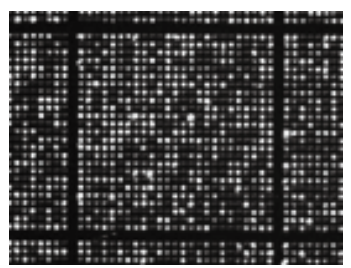

(b) 磁気スポツト型
図 7 シリコン型と磁気スポット型の細胞収容比較

スクリーニングプロセスまでを一気に自動化させることも実 現可能にしている。

また実際に臨床での応用を目指す場合, 患者の負担をでき るだけ軽くするために, 採血量は極力減らさなければならない。 一般的な検査用採血管の容量は約数 $\mathrm{mL}$ 程度で，概ね $10 \mathrm{~mL}$ 以下の採血量であり，臨床でも同等の採血量に抑制すること が好ましい。この限られた少量の血液のなかに含まれる頻度 の少ない細胞を効率よく回収するためには, チップへの細胞 投入量に対してチップ上にトラップされる細胞の数ができる だけ同じになることが好ましい。つまり $100 \%$ に近い細胞利 用率が得られるような性能を有するチップが開発されること が目標となってくる。表 1 は従来のシリコン型マイクロウェ ルアレイチップと磁気スポットアレイチップ(マイクロウェル 型)の比較データである。また図 7 は, 実際に両者を比較した ときの写真である。シリコン型マイクロウェルアレイチップ はマイクロウェルへの収容率が低いため, ウェル数の 4 倍の 細胞を播種している。また磁気スポットアレイチップはその 効果を見込んでスポット数の 0.65 倍に減らした細胞数で播種 した。シリコン型マイクロウェルアレイチップの方は，4倍 の細胞濃度であるにもかかわらず 1 回の播種でのウェルへの 収容率は $50 \%$ 程度である。よって, 細胞の利用率は $12 \%$ 程 度とふるわない。この結果から実際に実験などに利用するには, 何度も細胞の播種と洗浄を繰り返し収容させていくことが求 められる。一方, 磁気スポットアレイチップの方は, ほぼ全 数の細胞がトラップされており，シリコン型と比較して圧倒 的な性能を有することがわかった。さらにISAAC 法にも対応 可能であることも実験によりわかっており, 今後, シリコン 型マイクロウェルアレイチップから磁気スポットアレイチッ プヘシステムをシフトしていく予定である。この高い細胞利 用率と ISAAC 法によって, 抗体探索だけでなく様々な用途へ の応用へも展開していく可能性もある。例えば, ガンの治療. 診断, 各種薬郕の薬理作用の解析, 環境関連分野(環境ホルモ ンなど)などにも貢献できるものと期待される。

磁気スポットアレイチップの細胞利用率は, 今後患者から 取り出される少量の血液サンプルを評価するような事例で大 きなアドバンテージとなる。テーラーメイド医療のように同 じ病気であっても患者の状態は個々でばらばらであり，例え ば同じインフルエンザであっても細かな変位によって抗原性
を変えて行ってしまうような場合，患者によって異なる免疫 療法が必要となる。本チップは, 感染症やガンなどに対して 免疫機能を発揮する抗体を患者個人ごとにスクリーニングし てやることなどにより，個の医療を実現することが期待される。

\section{7. まとめ}

以上，筆者が開発してきたバイオチップとそのめっき技術 導入による高機能化について簡単に述べた。めっき技術導入 による利点は, 本稿で指摘したところだけではなく, 安価で バッチ処理が可能, 設備も比較的簡単ですむことなど数多く ある。また，めっき技術は，先端的なデバイスにおいてプラ スアルファの要素として取り入れることで優れた機能をそれ にもたらすことがわかった。近年さかんに医工連携という言 葉が叫ばれるようになり, 電子技術や半導体技術のようなハ イテク技術だけではなく，このような昔から親しまれてきた 成膜技術をうまく取り入れていくことで，これまで接点の少 なかった医療用アイテムの技術進歩を実現し，ひとの役に立 つ技術としての発展が望まれる。

\section{謝辞}

本研究に関して富山大学医学薬学研究部免疫学講座の村口 篤 教授, 岸 裕幸 准教授, 高見幸子氏, 軟磁性膜開発に関し て関東学院大学 工学部物質生命科学科 小岩研究室のご協力 に深く感謝の意を表する。また, 本研究は文部科学省地域イ ノベーション戦略支援プログラム「ほくりく健康創造クラス ター」および日本学術振興会科学研究費補助金基盤研究 C (22510128)により行われた。ここに感謝の意を表する。

(Received August 30, 2011)

\section{文献}

1 ) A.Jin, T.Ozawa, K.Tajiri, T.Obata, S.Kondo, K.Kinoshita, S. Kadowaki, K.Takahashi, H.Kishi, T.Sugiyama, A.Muraguchi ; Nature Medicine, 15, 1088 (2009).

2 ) A.Jin, T.Ozawa, K.Tajiri, Z.Lin, T.Obata, I.Ishida, H.Kishi, A. Muraguchi ; European Journal of Immunology, 40, 3591 (2010).

3 ) Z.Lin, A.Jin, T.Ozawa, K.Tajiri, T.Obata, I.Ishid, F.Jin, H.Kishi, A.Muraguchi ; Biochemical and Biophysical Research Communications, 395, 251 (2010).

4 ) 廣瀬優紀, 福井 航, 東森 充, 多田隅建二郎, 金子 真, 新井健 生, 坂田泰史, 山本一博, 川原知洋, 山西陽子, 新井史人; 計測自動 制御学会論文集, 47, 221, (2011).

5 ）小幡 勤; 表面技術, 59,382 (2008).

6 ）竹田拡史, 高梨 博, 小幡 勤, 小岩一郎; JPCA SHOW2011 アカ デミックプラザ, AP-07 (2011).

7 ) K.Ino, M.Okochi, N.Konishi, M.Nakatochi, R.Imai, M.Shikida, A.Ito, H.Honda ; Lab on a Chip, 8, 134 (2008).

8 ) H.Lee, Y.Liu, D.Ham, R.M. Westervelt ; Lab on a Chip, 7, 331 (2007).

9 ) M.Tanase, E.J.Felton, D.S.Gray, A.Hultgren, C.S.Chen, D.H.Reich ; Lab on a chip, 5, 598 (2005).

10) A.Jin, T.Ozawa, K.Tajiri, T.Obata, H.Kishi, A.Muraguchi ; Nature protocols, 6, 668 (2011).

11) Y.Tokimitsu, H.Kishi, S.Kondo, R.Honda, K.Tajiri, K.Motoki, T. Ozawa, S.Kadowaki, T.Obata, S.Fujiki, C.Tateno, H.Takaishi, K. Chayama, K.Yoshizato, E.Tamiya, T.Sugiyama, A.Muraguchi ; Cytometry Part A, 71A, 1003 (2007). 